\title{
Social Determinants of Education in the Postmodern Society
}

\section{KEY WORDS}

education, postmodern society, globalization, society

\begin{abstract}
Mühlpachr Pavel, Social Determinants of Education in the Postmodern Society [Społeczne uwarunkowania edukacji w społeczeństwie ponowoczesnym]. Kultura - Społeczeństwo - Edukacja nr 2 (4) 2013, Poznań 2013, pp. 37-45, Adam Mickiewicz University Press. ISBN 978-83-232-2708-3. ISSN 2300-0422

The situation of man in the beginning of 21st century is known as the postmodern. The concept of postmodernism indicates theoretically more or less elaborated opinions on current status of the process of globalization. The process of globalization does not produce only progress and positives but also threats, risks and transformation of man which are not only humanizing. The problem of postmodernism is mastery of plurality, heterogenity and otherness of ways, values and experiences of life, specialization of branches of science and societal development trends so that it contributes to dignified human life in society. The concept of postmodernism and its consequences for education of the younger generation project into conceptions of educational institutions, education in the family, but they also find their reflection in state policy due to the younger generation. Social changes, which occured at the end of 20th century, are part of global context of economical, political, social and cultural evolution. Their reach and importance must be seen into the future and in these wider connections.
\end{abstract}

The situation of humans at the beginning of the $21^{\text {st }}$ century is considered to be postmodern. The term postmodernism stands for more or less developed theories of the current conditions of modernization processes and particularly the outcomes of these processes. Modernization results not only in positive progress, but also in threats, risks, and transformation of people, which is not always humanizing, enriching the value of life, but exactly the opposite. As a paradigm, postmodernism postulates the plurality of attitudes, opinions, approaches, contemplation, the plurality of rational treatment of the social reality in its development and changes. 
Postmodern philosophy sees humans as having different approach towards the current world - it demands shift of our way of thinking and value orientation from quantitative and one-dimensional to qualitative, and multi-dimensional (Jirásková, 1997).

Postmodern thinkers define the postmodern society as a society, which is:

- permissive - a society, which allows more than traditional societies (for example drugs, homosexuality, sex without taboos, different forms of relationships between couples, difference in educational institutions);

- ludic - a society that likes games and does not consider work to have a major value in life. Occupation and work performance are not perceived as a significant field for self-realization. Elements of "game” are also transferred into work, young people stay at work as long as it is entertaining and does not cause troubles. Whenever work causes problems and looses its entertaining factors and game like characteristic, is time to leave it and find another one („life is to be enjoyed not worried about");

- secularized - the majority of activities does not have religious character, and if it does, than not in the sense of traditional Christianity (but rather sects, new religious movements, etc.). Spiritual values of an individual life are saturated from several sources focused on one's life without strong relation of the individual and the society. Society is not perceived as a complex where the individual is a part;

- post-moral - morality is out-of-date and moral values are perceived more as a luxury;

- post-heroic - it is not the heroes who educate, but transformed heroes (mutants and virtual idols);

- buck-passing - a society where it is possible to justify and vindicate virtually everything;

- post-educational - education is out-of-date, because life itself is the best teacher;

- globalized - the existence of every society depends on the ability and the extend of involvement of the worldwide society in dealing with global problems.

It is questionable, whether we have appropriate means to positively deal with globalization processes.

The main problem of postmodernism is how to deal with plurality, heterogeneity, and different lifestyles, values, experiences, specialization of sciences, and worldwide social developments, so that it will contribute to human dignity in a society.

It is an open and never ending discussion on the possibilities and limits of an individual; and about the existence of the human world and approaches towards it through understanding and finding of spaces for self-realization, including different risks and needs to cope with them. Professionals in the field of social sciences, 
and mainly those, who deal with the education of young generations are aware of the increasing demands of educational tasks. Urgent are also the educational problems of many pupils, students, clients, inmates, and the whole generation.

Great spectrum of behaviors and lifestyles opens before individuals, who need to choose between them. The choice will afterwards influence the quality and richness of their socialization process, where education plays an important role. From this point of view, we cannot forsake education and its role, but quite the contrary.

It is important to make topical the goals of education, its instruments, and individualized approaches in a wide social context of global processes. It is also necessary to innovate teacher training and teacher readiness to help the young generation dealing with social problems (via educational actions capacitate students to deal with problems of their lives).

The interpretation of post-modernism and its outcomes for education of the young generation projects itself also into the conception of educational institutions, the conception of upbringing in the family, and reflects itself also in the country policies towards the young generations.

Social changes, which came around at the close of the last century, are part of the worldwide economic, political, social and also cultural changes. The impact and significance of these changes must be considered into the future and in a broad context.

We should mention the social aspects or if you like the determinants of the educational activities. We can think about the following aspects of social changes:

1. Freedom of speech, great possibilities to travel, great flow of information (sometimes antagonistic), markets offering different kinds of goods, attacks and underbidding of advertising, which instigates consumption. It shows how easily and with no effort one can become rich and successful, how one can buy and spoil oneself even without money. Many young people are then convinced that democracy means life without any effort, without duties, where one can finally exercise own individual right for limitless happiness, joy, fun, health and satisfaction. The present information boom produced by the mass media is one of the causes of unrealistic and simplified life conceptions. Entry of young people into real conditions of life then significantly contrast with the vision they based on the media image.

In spite of the fact that parents and teachers warn against such an idealized social reality, the warnings are not accepted by the young generation.

2. Economic prosperity is the priority of present society, where the regulations for reaching prosperity are mainly legal (legality or illegality), without application of ethical and social aspects. In this context, everything what brings revenue is valued. Intelligent and far-seeing is a person, who knows how to make money, and on the other hand dumb is the one, who does not know how to make it. It is 
not important whether money is earned honestly or not. Orientation on success and performance instigates the need to compete with others and the effort to be always better than the competitors. Every mean that leads to such an outcome is seen as a value in the conception „The end justifies the means”. Accompanying phenomenon of the success orientation is the need of wealth cumulating, symbols of wealth (particular brand of car, holidays of certain level, etc.) and anxious destructive haste that causes stress. The situation is often dealt with by adjusting one's performance condition via the use of drugs. The possibility of professional selfrealization changes as a result of economic reforms. Unemployment is for many people, not only young but also for those with young families, great economic and also socio-psychological problem. This problem cannot be mitigated only by payments of unemployment social benefits. More men than women experience socially psychological oppression of unemployment. Women can more often find their self-realization in childcare and running the household. We should also mention the fact that we now experience greater professional mobility, more possibilities of professional self-realization mainly in the field of entrepreneurship and social services. There are many lucrative jobs that are very demanding and with very long working hours. Employers are interested in younger workers, often limited by the age of 35. It is expected that such people will be adaptable, with interest in effective and intensive self-education, but also already having their parental obligations. Frequent phenomenon is the take over of the educational role of children by one of the parents or designating it to the grandparents. However, they cannot accomplish the educational role throughout the whole development course of an adolescent. To reach such an objective is for grandparents, even though they often try hard, beyond their strengths. Whenever educational failures occur in such situation, the blame is laid on the grandparents.

3. As a consequence of overwork, we naturally after some time witness tiredness and exhaustion of the parents. Parental care is than narrowed and reduced into ensuring satisfaction of material needs, organization of family and control. Children are controlled only whether they fulfill their school duties or not. Time stress in the family leads to the need to solve problems objectively, fast, and often without patience. It is not needful to deal with worries, concerns and losses, because we need to "go on". Haste leads parents to focus on solution of the occurred problem, but not on the causes. Children often miss clear parental example of how to overcome difficulties, ways of searching and finding mental balance, ways of positively solving misfortunes, ways of getting balance and strength for dealing with a bad luck, defeats and disappointment. In contemporary family we see less possibilities and abilities of expressing emotions, communicating them, and less willingness and need of sharing them with other family members. This is connected with the process of identification with values, which take place in the sphere 
of emotionality. In case that the family does not provide enough opportunities for inward emotionality and experiences of inward emotions are not encouraged (according to the level of ontogenesis), the result will be a poor and inconsistent system of values. Without the existence of values, it is not possible to understand specifically human conditions as shame, duty, honor, pride, self-esteem, respect of values and other humans (Rollo, 1993). Families are losing the ability of open communication, listening to one another, sharing information and experiences, positive and negative value contents, successes and failures, finding possibilities and support. All of this influences family solidarity and formative effects on the members, which influences their growth of personalities. Busy, inpatient way of family life does not provide enough space for emotional security and real selfidentification. Deficit of emotional support of the child and scarcity of emotional acceptance of the child leads to emotional deprivation. Emotional weakness of interpersonal relations in the family decreases the efficiency and activation of a child in respecting rational and justified demands of his/her parents.

4. The promotion of intellectualization of mental processes in recent time, emphasis on rationality and its use in adaptation processes reached a point, where we can perceive the effects of the processes. They lead to atrophy of emotionality and repression of emotions in favor of the desired performance (Pollman, 1993). Emotional poorness in this way endangers the joys and sufferings that necessarily accompany our social relations with partners, children, parents, relatives, friends, coworkers, ethnic groups, etc. Friendship, love, thankfulness, sorrow, responsibility, erudition, and the whole cultural and historical heritage are then just empty concepts without motivating and activating forces. The range of revaluation of life processes and activities decreases in every stage of an individual life and the whole humankind. Human life becomes narrower and egocentrically restricted. We can talk about the crisis of values and normative systems in the society, about estrangement of one another and undermined faith in life and its values. The speed of changes that surround us and their fragmentation also contributes to emotional poorness as it is impossible to process them internally. There are very sensitive areas, where people have no key for organizing the changes, because of their young age, immaturity or background. That is why only very strong events break into the mind and that is why we need constantly stronger, more shocking experiences and are becoming used to ever-stronger stimuli. It is also why we on the other hand scorn everyday life for not being full of such unnaturally provocative events. The threshold of sensitivity rises as we get used to ever-stronger stimuli, which leads to the inability of sensing delicate incentives. The insatiable desire for stronger stimuli manifests itself in the search for something new, different, provocative and shocking. Producers respond to this phenomenon by bringing out commercial production and commercial entertainment, which is 
valueless (for example: American action movies, pulp romances, South American soap operas with infinite number of episodes that will be still watched even by our grandchildren, etc.). Also the mass media succumb to the pursuit of sensations (Rollo, 1993).

5. Pressure on the family budget rises and so rises the pressure on both parents to be fully employed. This strain than influences financial possibilities of the family and time that can be devoted to common family interests and spending free time together. Free time activities are still part of a family life as far as the family budget permits it, and where such activities are passed on as a value. In this context we have to point out, that the number of activities provided by schools and educational institutions free of charge or for symbolic fee decreases (for example sport and art clubs). These clubs were aimed also at children, who came from families that did not provide such activities because of financial, temporal or value orientation reasons. On the other hand, we can perceive a boom of free time activities and courses that are associated with financial demands, which lead to great selectivity of children. The current network of free time activities focus on children and adolescents, whose parents are able to finance them and instigate the performance and persistence of their children. The network is also very unevenly spread out in the regions and so becomes inaccessible for some children, even though they would be interested in attending. The accessibility is getting worse as public transport companies cut more and more lines and as the fares become more and more expensive. Families that are economically weak or do not care about this sphere represent a great barrier for their children in participating in many of the activities.

6. Many families feature new concepts of coexistence and rising their children, which manifest itself in loose family relationships, parental focus on asserting their own lifestyle (own professional career, activities and rest), which influences the attitudes towards education, security, and functioning of the family. High divorce rate, rising children in single parent families, where parental roles change, produces difficult educational situation. This situation is typical for its fragmented way of rising children together with inconsistent goals and values in the rising process. The children are often left to care for themselves as a result of partnership conflicts in complete or incomplete families. The disorder of socialization in a family can remain hidden for a long time and manifest itself only vicariously in symptoms associated with different problems. It is very hard to distinguish them and even parents and guardians do not become conscious of them soon enough. They do not want to admit their faults and helplessness of their actions and seek the help of professionals. The problems of the child and his/her socially pathological behavior becomes worse, and despite the efforts of professional institutions, is being solved only after it becomes very serious, when 
the consequences are visible without any doubt. Extreme plurality of styles in rising children often does not follow the developmental goals of an individual in certain stages of his/her ontogenesis. Medical doctors, educational counselors, and teachers often point out the problems, but the parents are not accepting their suggestions.

7. Schools and the concept of educational process also changes as a consequence of social changes. We can shortly describe the changes as follows:

- Upbringing processes at school are supposed to fine-tune the upbringing in a family. This fine-tuning has several qualitative levels. However, in some cases, we cannot talk about fine-tuning of good family care, but about corrective actions against social deviation of a child or adolescent. (Kapr, Linhart, 1994). Currently we do not have a system of approaching peripheral deviations in a society. That is why education systems do not effectively manage social deviations of an individual. At the same time, we see a growth of institutions that are trying to address these problems. Next to state institutions there are private organizations, charities, and non profit organizations. However there is no system, which would care and help from the moment of emergence of a problem or conflict to the final reintegration into the society. From the point of view of an individual, the focus should be on instigating of the process of maturing and assuming the responsibility for own development, own actions, and search and discovery of adequate conditions for self-realization in a society. In this context it is necessary for education to introduce and prepare young people for difficulties and barriers in life, and teaching the ways of how to overcome them.

- Recent school systems concentrates on efficiency of educational processes, on students' performance, and on reaching the required level of knowledge. The demanded level of mastered curriculum rises mainly in the final years of elementary school and particularly at the secondary school. Educators are than led by the endeavor of well preparing their students for the following school levels and meeting the required demands. By doing so, they do not respect the adequacy of the curriculum and concentration on individual subjects. Many pupils and students feel frustrated as they cannot reach success because of such inadequacies. As they cannot master the demanded knowledge, they start to perceive negatively not only the curriculum, but also the school as an institution and education as a value. Some students, in order to meet the growing requirements of school, reduce or leave many free time activities (artistic, sport, recreational, etc.), which were a source of positive stimuli for mental balance. Failures and problems with learning often reflect itself in the family and cause conflicts with parents. Inadequately saturated need of success negatively influences the self-image, self-confidence, confidence in own abilities and usefulness, experience of meaning and meaning of life in general. Such a person then searches for alternative sources of this saturation. Among the 
alternative sources are also gangs of criminal individuals simply because one can find recognition and personal value there. It does not matter that the values are not pro-social and often the opposite of the socially accepted and requested. In this context, even drugs or crimes can become attractive.

We need to analyze the changes of educational climate in the social environment (not only primary) as the consequence of worldwide changes and process characteristic for post-modern society. In this context, the difficulty of the situation of a young individual is obvious. We can see ever growing demands on the individual, increased difficulties of integration into society, and problems of finding socially accepted and individualized sphere for self-realization.

\title{
Literature
}

Černíková V. (2002). Prekriminalita dětí a kriminalita mladistvých, kterým byla uložena ochranná opatření. Praha, s. 5-15

Dorotíková S. (2000). K evropským myšlenkovým tradicím. Praha, s. 126-129

Hubík S. (1999). Sociologie vědění. Praha

Jirásková V. (1997). Vzdělávání v postmoderní době. (W:) Hodnoty a vzdělání. Praha, s. 72-83

Kapr J., Linhart J. (1994). Sociologické pojmosloví, sv. 1. Praha, s. 53

Lorenz, K. (1990). 8 smrtelných hř́chü. Praha, s. 32-42

Pollman Ch. (1993). Represe emocí ve prospěch rozvoje kapitalismu. „Bulletin pro Sociální pedagogiku", č. 3, s. 37-41

Rollo V. (1993). Emocionalita a racionalita. Praha, s. 176-186

Skalková, J. (1996). Problémy mládeže v kontextu postmoderního myšlení. (W:) Mládež a sociálně negativní jevy. Praha

\section{Społeczne uwarunkowania edukacji w społeczeństwie ponowoczesnym}

\author{
Streszczenie
}

Sytuację człowieka na początku XXI wieku określa się jako ponowoczesną. Pojęcie ponowoczesności odnosi się do mniej lub bardziej teoretycznie opracowanych poglądów dotyczących aktualnego stanu modernizacji, zwłaszcza jej skutków. Modernizacja to nie tylko postęp, efekty pozytywne, lecz także zagrożenia, ryzyka i przemiany człowieka, które nie zawsze wzbogacają wartość człowieczeństwa, mogą też być jego przeciwieństwem. Ponowoczesność jako paradygmat deklaruje pluralizm postaw, poglądów, podejść, pluralizm racjonalnego postrzegania rzeczywistości społecznej w jej rozwoju i przemianach.

Za główny problem ponowoczesności można uznać właśnie przyswojenie pluralizmu, heterogeniczności i różnorodności sposobów życia, wartości, doświadczeń, specjalności dziedzin wiedzy i ogólnospołecznych trendów rozwojowych w taki sposób, by zachować godność ludzkiego życia. 
Chodzi o otwartą i żywą, trwającą całe życie dyskusję o możliwościach i ograniczeniach jednostki, o egzystencji świata ludzi w perspektywie zrozumienia i szukania w nim miejsca dla samorealizacji, wliczając $\mathrm{w}$ to różnego rodzaju ryzyka i konieczność radzenia sobie $\mathrm{z}$ nimi. Przedstawiciele nauk społecznych, zwłaszcza ci, których kompetencje zawodowe obejmują wychowanie młodego pokolenia, świadomi są wzrastających wymagań związanych z pracą wychowawczą oraz z koniecznością konfrontacji z problemami wychowawczymi uczniów, studentów, klientów, pensjonariuszy, dorastającego pokolenia.

Człowiek ma przed sobą szerokie spektrum możliwości zachowań i stylów życia, których wybór determinowany jest przez jakość i bogactwo procesu socjalizacyjnego, w którym z kolei wychowanie odgrywa znaczącą rolę. Patrząc z tego punktu widzenia, nie można zrezygnować Z wychowania i jego celów. Z uwzględnieniem szerokiego społecznego kontekstu ogólnoświatowych procesów należy ponownie zakreślić horyzont celów wychowania, kształcenia, środków do ich osiągania, należy stosować indywidualne podejście i w innowacyjny sposób przygotować pedagogów do pomagania dorastającemu pokoleniu w rozwiązywaniu problemów społecznych, kształtując w nim poprzez pedagogiczne oddziaływania zdolność do rozwiązywania problemów życiowych.

Koncept ponowoczesności i jego skutków dla wychowania młodego pokolenia rzutuje także na rozumienie istoty instytucji wychowawczych, na rozumienie wychowania w rodzinie, jak również na politykę państwa wobec młodego pokolenia.

Przemiany społeczne zapoczątkowane w poprzednim wieku stanowią część składową szerszych, ogólnoświatowych tendencji rozwojowych o charakterze ekonomicznym, politycznym, społecznym i kulturowym. Ich zakres i znaczenie powinny być rozważane z uwzględnieniem przyszłości oraz właśnie tego szerokiego kontekstu. 